\title{
Assessment of Flood Hazard Mapping Based on Analytical Hierarchy Process (AHP) and GIS: Application in Kencong District, Jember Regency, Indonesia
}

\author{
Muhammad Asyroful Mujib* (D), Bejo Apriyanto, Fahmi Arif Kurnianto (D), Fahrudi \\ Ahwan Ikhsan (D), Elan Artono Nurdin (D), Era Iswara Pangastuti, Sri Astutik \\ Department of Geography Education, Universitas Jember, Jl. Kalimantan 37 Jember, East \\ Java, 68121, Indonesia
}

Received 2 October 2021/Revised 4 December 2021/Accepted 14 December / Published 22 December 2021

\begin{abstract}
Flood is one of the most frequent hydrometeorological disasters which leads in economic losses. The first step in flood disaster mitigation efforts is mapping vulnerable areas. Kencong District frequently affected by the annual flooding event. This study aims to assess flood hazard mapping by integrating the AHP method and Geographic Information System. This study used a descriptive quantitative approach through the correlation matrix of the AHP model for each physical environmental factor. These factors include slope, altitude, distance from the river, soil type, Topographic Wetness Index (TWI), and Curvature. Furthermore, with the Geographic Information System (GIS), the weighted overlay stage was carried out to obtain the results of flood-prone areas. Based on the AHP analysis, the most significant factors in determining flood-prone areas were the distance from rivers, slopes, and TWI. The results of flood-prone areas mapping were divided into five classes: from deficient $0.02 \%$, low $4.26 \%$, medium $37.11 \%$, high $51.89 \%$, and very high $6.72 \%$. Validation of GIS mapping results with data in the field has an AUC value of $84 \%$, which indicates that the prediction of the AHP-GIS model is perfect in flood-prone areas mapping in the Kencong District. The integration of AHP method and Geographic Information System in flood hazard assessment were able to produce a model to evaluate the spatial distribution of flood-prone areas.
\end{abstract}

Keywords : Flood Hazard Mapping; Multi-criteria decision analysis; AHP Model; GIS; Jember

\section{Introduction}

Flood is one of the natural disasters with a high frequency of occurrence that can cause damage to the natural environment, buildings, property, and even fatalities (Kia et al., 2012; Vorogushyn et al., 2012). It is estimated by Feng \& Lu (2010) that of the total economic losses from all disasters, $40 \%$ are caused by floods. Djalante \& Garschagen (2017)

*Corresponding author.

Email address :mujib@unej.ac.id (Muhammad Asyroful Mujib) 
describe that in Indonesia during the period 1900-2015, floods and earthquakes were the most frequent hydrometeorological disasters compared to other disasters. Urban areas have a high disasters susceptibility based on their size and population density (Zheng et al., 2013). Dynamic changes such as changes in land use, land cover, urbanization activities, and increased household density in flood-prone areas will increase the potential for flood damage (Pelling, 2003; Tehrany et al., 2015). Flood is also directly caused by high rainfall, which affects the volume of runoff, filling, and even exceeding the drainage channel network, resulting in very high discharge downstream and at the outlet of the watershed (Youssef et al., 2009)

Jember Regency has a high frequency of flood events. Jember Regency and 17 other districts in East Java in 2020 had a high-Risk Index for floods with a score of 36.00 (BNPB, 2021). In 2019, BNPB also published sub-districts or villages prone to flooding throughout Indonesia. Based on this data, there are 216 villages in 31 sub-districts in Jember Regency, identified as "Medium" flood hazard class (BNPB, 2019). One of the 31 flood-prone subdistricts in Jember Regency, which is almost every year affected by floods including Kencong District. Kencong District is included in the downstream Tanggul watershed area, a watershed in Jember Regency that often overflows during the rainy season (Ainunnisa et al., 2020).

Villages in the Kencong District that are included in the Tanggul watershed area and are often affected by floods are Kencong, Kraton, and Paseban Villages (Haq et al., 2020). Also added by Haq et al., (2020) sourced from the report of the Public Works Department of Highways and Natural Resources of Jember Regency Natural Resources Coordinator Area of Kencong and Gumukmas Districts (2018) that from 1994 to 2018 in the last 25 years, there have been 27 flood events, river discharge during flood events ranges from $461-814 \mathrm{~m}^{3} / \mathrm{s}$ with an average rainfall of 76-138 mm. Flood history is also emphasized by the Public Works Department of Highways and Natural Resources of Jember Regency Natural Resources Coordinator Area of Kencong and Gumukmas Districts (2021), which stated 100 mm/day rainfall in every time the Tanggul watershed, the Tanggul River discharge would rise and fall. Water carries mud sedimentation from upstream, which can gradually cause the river body to become narrower; even when the peak discharge conditions are flooded, it will break the river embankment, and so far, nine times the river embankment has collapsed due to overflowing river discharge.

Mapping of flood-prone areas and historical records of events have a relevant role in identifying flood-prone areas, the intensity of events, the depth of flooding, and the damage 
that will be caused. There are three main approaches to mapping flood-prone areas: a physical-based approach, an empirical approach, and physical modeling (Mudashiru et al., 2021; Teng et al., 2017; Bellos, 2012). Physical modeling requires experiments to validate the model's predictive performance (Mudashiru et al., 2021). It can then be simulated in 1, 2, and 3-dimensional forms using a numeric model to determine the process of flooding (Carmo, 2020; Balica et al., 2013), such as numerical models using Delft3D in the Tanggul watershed (Haq et al., 2020), the use of HEC-RAS in the Singojuruh sub-district and the upstream Citarum watershed (Bachri et al., 2021; Siregar \& Indrawan, 2017). The physicalbased approach is exact for flood prediction but requires many input data such as hydrological, topographic, morphological, and remote sensing data processed in GIS (Ji et al., 2012).

The empirical approach is categorized into three models, namely (1) multi-criteria analysis (Handini et al., 2021;Ajjur \& Mogheir, 2020; Chakraborty \& Mukhopadhyay, 2019; Dahri \& Abida, 2017;Danumah et al., 2016; Kazakis et al., 2015); (2) statistical methods including bivariate and multivariate models (Costache, 2019; Ahmed M. Youssef et al., 2016); (3) machine learning and Artificial Intelligence models (Costache et al., 2021; Eini et al., 2020; Shafizadeh-Moghadam et al., 2018). From 2000-2021, the most widely used approach among the three approaches is the empirical approach with about $46.2 \%$, the Physical modeling approach of $43.8 \%$, and the physical-based approach of $10 \%$ (Mudashiru et al., 2021). The multi-criteria analysis model using the Analytic Hierarchy Process (AHP) method as an empirical approach is the most widely used method (Mahmoud \& Gan, 2018). The AHP method is a weighted evaluation process based on pairwise comparisons of each parameter which is then ranked and evaluated to choose the best solution for a problem (Saaty, 1990, 2004; Mudashiru et al., 2021).

Multi-criteria analysis for flood analysis and mapping of flood-prone areas has been successfully applied with the help of GIS and remote sensing (Rahmati et al., 2016; Das, 2018, 2020). It was further explained that combining the AHP method with GIS could be a reliable, efficient, accurate method and could be easily applied in other regions of the world (Danumah et al., 2016; Das, 2018; Chakraborty \& Mukhopadhyay, 2019). On the other hand, the drawback of this AHP method is the selection of indicator weight values with based on expert opinion. The assessment has subjectivity and cognitive limitations (Pourghasemi et al., 2014; Papaioannou et al., 2015). However, this weakness is reduced by assessing the consistency of the ratio, Satty (1980) determined that the threshold for the consistency of the ratio should be less than $10 \%$ to obtain a coherent value between the weighted variables. 
Flood-prone areas mapping in various studies require various topographic parameters, hydrology, geomorphology, and climatology. Topography parameters were extracted from Digital Elevation (DEM), hydrology such as rainfall and river discharge, and geomorphology such as river flow networks, landforms, and land use. This data was obtained using remote sensing and processed in GIS (Wang et al., 2019; Arseni et al., 2020; Das, 2018, 2020). The parameters used in this study were slope, elevation, distance from the river, soil type, Topographic Wetness Index (TWI), and curvature. This study aims to assess flood hazard mapping by integrating the AHP method and Geographic Information System in Kencong District, Jember Regency, which is included in the downstream Tanggul watershed area.

\section{Study Area}

This research was carried out in the downstream Tanggul watershed, which is included in the administrative area of Kencong District. This area is located between coordinates 76147.105-757826.029 mS and 9081002.236-9085265.055 mT with an area of $59.64 \mathrm{~km}^{2}$. the western part of Jember Regency and directly adjacent to Lumajang Regency. Kencong District consists of five village: Kencong Village, Wonorejo Village, Kraton Village, Cakru Village, and Paseban Village (Figure 1). This area is downstream of the Tanggul watershed whose river empties into the Indian Ocean so that the altitude in the research area is between 0 to 31 meters.

Geologically, Suwarti \& Suharsono (1993) explained that most of the research area is included in the Argopuro Tuff Formation in the form of Interval tuff, tuff breccia, and tuffaceous sandstone. Argopuro Tuff formed in the Pleistocene Period, while in the southern part, it is included in the Alluvium formation in the form of Clay, mud, sand, gravel, gravel, and boulders. The southern part, which is close to the beach, is a coastal deposit formation in loose sand containing magnetite and formed in the Holocene Period as surface deposits.

Climatically, based on observations of rainfall for ten years (2009-2019) from three observation stations, namely Pondok Waluh, Padingan, and Kencong rain stations, the rainfall in the study area ranged from 1663-1947 mm/year. The intensity of monthly rainfall increases from December to February. If the rainfall in the Tanggul watershed area reaches $100 \mathrm{~mm} /$ day, the rivers passing through Paseban Village, Kraton Village, and Kencong Village will overflow and cause flooding (Haq et al., 2020). Land use in the research area is dominated by agricultural land in rice fields $(48.46 \%)$ and plantations/gardens by $33.67 \%$, while settlements are $8.82 \%$. 


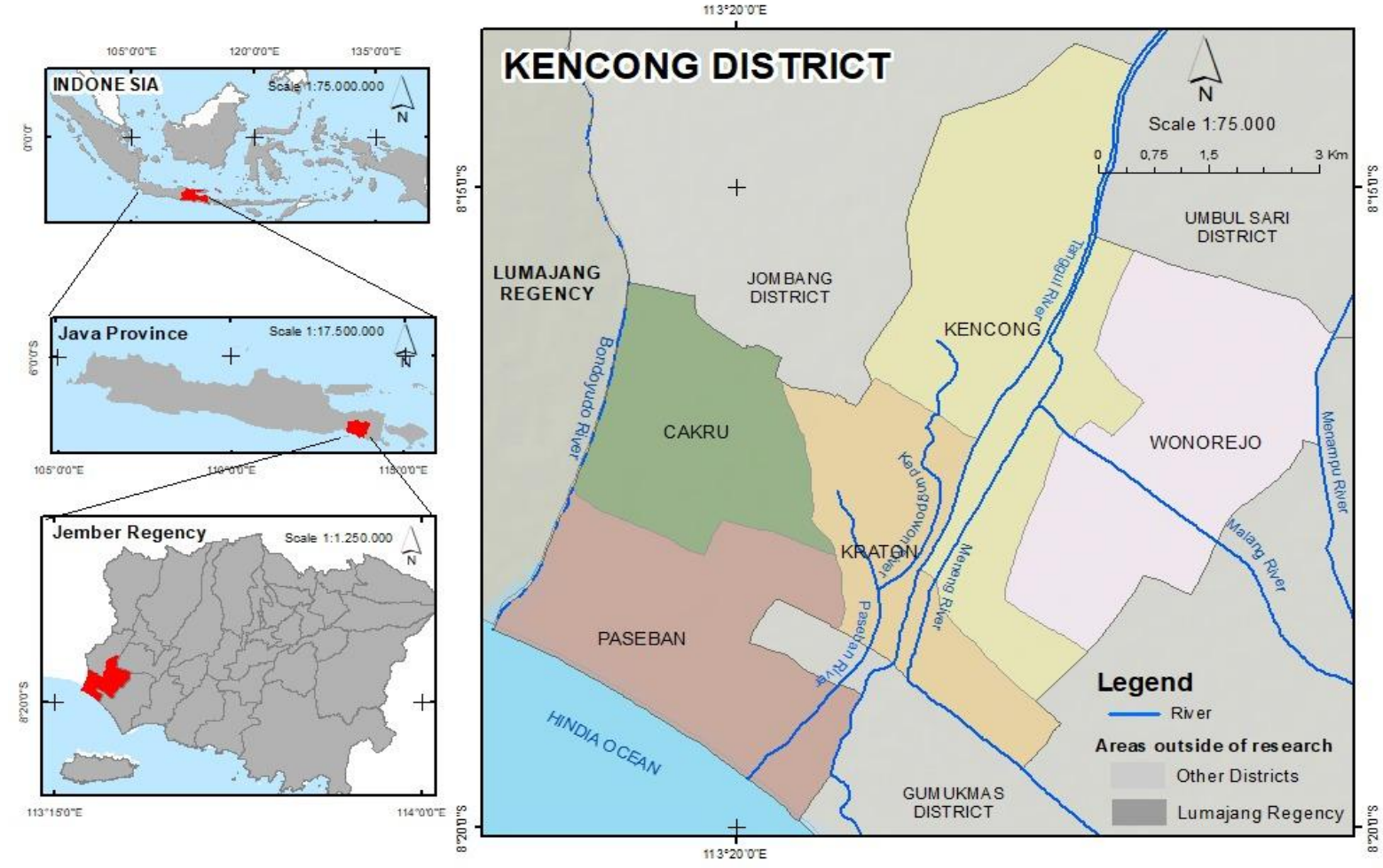

Figure 1. The Study Area

\section{Methods}

The application of Geographic Information Systems and AHP for flood-prone areas mapping in the research area includes four stages: (1) Collection of the flood inventory mapping; (2) Determine the flood conditioning factors; (3) Analyzing flood-prone maps using the AHP method; and (4) Validation of results from flood-prone areas mapping.

\subsection{Collection of The Flood Inventory Mapping}

The inventory of flood locations in the research area comes from the National Disaster Management Agency (BNPB, 2019) regarding flood event records and field surveys. The limited data from BNPB related to the location of the incident includes the name of the village, needs to be reviewed by researchers utilizing field surveys and conducting interviews with the community due to the inventory map is an essential factor to see the opportunities and possible occurrences of disasters in the future (Tien Bui et al., 2012). The results from the inventory of flood locations will be used as validation of flood mapping results using AHP. 


\subsection{Determine The Flood Conditioning Factors}

The thematic variables used for mapping flood-prone areas in this study were extracted from satellite imagery data, Indonesian topographical maps, and secondary data from government web sources and government agencies. The Shuttle Radar Topographic Mission (SRTM) Digital Elevation Model (DEM) with a resolution of $30 \mathrm{~m}$ was downloaded from the USGS Website (earthexplorer.usgs.gov). The DEM data is processed in ArcGIS 10.8 software to determine slope maps, elevation maps, Topographic Wetness Index (TWI) maps, and Curvature maps. The Indonesian Topographical Map is used to determine the administrative boundaries of the research area and river maps. Web sources are used to determine the type of soil that affects the drainage process.

Slope: The slope has a dominant role in influencing water velocity, flood strength, and infiltration (Das, 2020). The slope is displayed in degrees and is classified into five categories: <2 degrees; 2-4 degrees; 4-6 degrees; 6-8 degrees; and >8 degrees. The smaller the degree of slope, the more vulnerable it is to flood disasters, so the value of the most significant weight is given.

Elevation: Elevation affects the direction of flow and movement and the flood's inundation depth. The elevation is a factor that significantly influences the classification of potential flooding and is the highest compared to slope and land use (Kia et al., 2012; Ho \& Umitsu, 2011). Furthermore, Ho \& Umitsu (2011) stated that in areas with the same elevation and landform, flooding does not always coincide due to the slope of the terrain and the water level flood. The altitude of the place is divided into five classes: <10 m; 10-15 meters; 15-20 $\mathrm{m}$; 20-25m; and $>25 \mathrm{~m}$.

Curvature: This parameter results from surface deviation from a flat plane. The method used in determining curvature is to apply a quadratic polynomial function to DEM data (Zhu, 2016). The curvature parameter is divided into concave, flat, and convex categories. The most influential factor prone to flooding is flat, followed by concave and convex.

Topographic Wetness Index (TWI):This parameter is very suitable for predicting the level of surface soil saturation due to in water-saturated soil, the soil has the potential to create overland flow (Youssef \& Hegab, 2019). Soulsby et al., (2010) also stated that TWI is a physical parameter of an area highly susceptible to flood inundation. The higher the TWI value, the more vulnerable it is to flooding, while the lower the TWI value, the lower the vulnerability (Das, 2018). TWI is processed directly from the SRTM DEM using ArcGIS 
10.8. TWI parameters are categorized into three classes: TWI values $>14$; $9-14$; and $<9$. TWI is calculated by Eq. 1 .

$$
T W I=\ln \frac{a}{\tan \beta}
$$

where TWI is the Topographic Wetness Index, $a$ is the contribution of the upstream area $\left(\mathrm{m}^{2}\right)$, and $\beta$ is the slope angle

The distance from the river: There is no agreement about how many critical distances have high flood hazards. The distance is different from one river to another. Small rivers can cause up to several meters from the riverbank, up to several kilometers in large rivers (Das, 2020). Das $(2018,2019)$ stated that the distance of 500 meters was the most vulnerable to flooding, while Samanta et al. (2016); Rahmati et al., (2016); and Ajjur \& Mogheir, (2020) mention 100 meters as the most vulnerable distance. The distance from the river in this study was analyzed by the Euclidian Distance method and categorized into five classes with 300meter intervals: <300 meters, 300-600 meters, 600-900 meters, 900-1200 meters, >1200 meters.

Soil type: Soil type maps are used to characterize permeability conditions and soil capacity to store and carry water (Hammami et al., 2019). The type of soil in the research location is divided into three categories: good drainage, medium drainage, and poor or impermeable drainage.

\subsection{Analytical Hierarchy Process (AHP) Model}

After all thematic maps were prepared and classified, the Analytical Hierarchy Process (AHP) model was applied to assign different weights to each parameter. AHP was developed by Saaty (1977). AHP is a structured model and can solve multi-factor problems, provide a numerical process for the consistency of the preferences, and evaluate ranking inconsistencies based on pairs (Satty, 1980; Fernández \& Lutz, 2010).

The application of the AHP method in this study consisted of two stages. The first stage is the primary classification for all parameters according to how vital each parameter is to the other parameters to calculate the weights. The second stage is to classify each parameter into subcategories. In two-stage processing, each factor will be assigned an arithmetic value between $1-9$, depending on the significance of that factor to the other factors paired. Satty (1980) conveyed the arithmetical value of the importance of the scale, which contains different criteria and values (1. Equal importance; 3. Moderate importance; 5. Strongly importance; 7. Very strongly importance; 9. Extremely importance; 2, 4, 6, and 8 
are intermediate values). An arithmetic value of 1 indicates that both factors are equally important. In contrast, an arithmetic value of 9 indicates that the factors in the row are very significant compared to the factors in the columns (Satty, 1980)

The first stage of the AHP method in this study used pairwise comparison with a 6 × 6 matrix (Table 1). After that, the value of pairwise comparison will be normalized to obtain a value used in the weighting of each parameter (Table 2). Consistency Ratio (CR) is used to evaluate pairwise ranking inconsistencies. CR compares Consistency Index and Random Consistency Index (RI) (Eq. 2). Subjective assessment is acceptable if the CR value is below or the same 0.10 , but if the CR is higher than 0.10 , the subjective assessment is inconsistent and needs to be reassessed to ensure realistic results (Saaty, 1990).

$$
\begin{aligned}
& C R=\frac{C I}{R I} \\
& C I=\frac{\lambda \max -n}{n-1}
\end{aligned}
$$

Where CR is Consistency Ratio, CI is Consistency Index (Eq. 3), RI is Random Index, max represents the principal eigenvalue of the matrix, and $n$ is the number of variables in the matrix. The calculation of the RI value is based on a paper from Saaty (1980). The value of RI depends on the number of factors; when the number of factors is six, then the value of RI is 1.24 based on (Satty, 1980).

The second stage is to classify each parameter into subcategories and assign a weight to each class. The maximum and minimum values for each class vary from 1 to 5 . Furthermore, from each class, the normalization is calculated to determine the weight of each class. The weight of each class is related to the impact of each class on the flood hazard. The slope, elevation, and distance factors from the river are divided into five classes, while the soil, TWI, and Curvature factors are divided into three classes.

Furthermore, the weight values of all classes in each parameter are combined with the weight values of all factors to calculate the flood Hazard Index (Eq. 4). The overall weight value for each factor is calculated by multiplying each factor's weight by each class of the same factor.

$$
\text { Flood Hazard Index }=\sum_{j-1}^{n} X i j \times Y j
$$

Where $X i j$ is the weight of class $i$ on variable $j, Y j$ is the weight of variable $j$, and $n$ is the number of variables. 


\subsection{Validation}

Validation and accuracy assessment of the analysis results of the multi-criteria analysis approach model, especially AHP, is one of the essential parts. Applying the Area Under Curve (AUC) based on flood event data in the field and historical records is a wellestablished tool for validating the AHP model due to its simplified nature, completeness, and proper fit with predictions (Tehrany et al., 2013). A value of 1 for AUC indicates the maximum value accuracy without bias effect, whereas in general, an AUC value of more than 0.8 is considered a very accurate and acceptable model.

This study divided the flood susceptibility map using the AHP method into five classes. Flood inventory points resulting from observations and interviews are mapped in the form of $\mathrm{X}$ and $\mathrm{Y}$ axes, and the identification of the number of flood events for each class is compared to the flood-prone output map. The percentage of total flood events and the percentage of pixels for each class is determined based on these data. Based on the data, the area under the curve is identified numerically by the Eq. 5 .

$$
A U C=\sum_{f=1}^{n=100} \frac{\left(X_{1}+X_{2}\right)}{2\left(Y_{2}-Y_{1}\right)}
$$

Where $A U C$ indicates the area under the curve, $X$ indicates the cumulative percentage of the area (from high to low vulnerability), $Y$ indicates the cumulative percentage of flood events, $l$ and 2 indicate two consecutive data points, and $n$ is the number of flood classes.

\section{Results and Discussion}

\subsection{Factors That Influence Flood Hazard Mapping}

Floods occur due to several topographic and climatic factors in an area. The influence of each factors is undoubtedly different and will produce an overview of locations prone to various levels of flooding. In this study, six variables influence the occurrence of flooding, which will then be modeled using the Analytical Hierarchy Process (AHP). Each of these variables will be discussed in detail below:

\section{Slope}

A slope is a field angle or gradient measured from the level of elevation change at a location (Zhu, 2016). According to Chakraborty \& Mukhopadhyay (2019), slope and elevation are considered disaster-forming factors because they have an essential role in turning flood hazards into disasters. Both are essential topographical factors (Das, 2018). 
Slope in an area will affect flow velocity, runoff rate, and infiltration, so that it can have an impact on flooding (Rahmati et al., 2016; Zhu, 2016; Das, 2018). In areas with high slope gradients, the water flow will also move quickly so that the infiltration process is reduced.

On the other hand, it will increase surface runoff; as a result, when the water flow is on a low or flat slope gradient, water will accumulate and stagnate. Slope variation in Kencong District is between $0^{\circ}$ to $12^{\circ}$. The slope class with the most significant weight value in this study is $0^{\circ}-2^{\circ}$ which is prone to flooding. This class range is about $78.6 \%$ of the research area (Figure 2a).

\section{Elevation}

Elevation has a significant impact on the spread of floods, especially on the direction of flood movement and inundation depth (Rahmati et al., 2016; Hammami et al., 2019). The principle of water movement is from a high location to a lower location so that lower locations with flat slopes will have a greater level of flood vulnerability (Das \& Pardeshi, 2018). Elevation variations in Kencong District are between 0 to 31 meters. The elevation class with the most significant weight value in this study is $<10 \mathrm{~m}$ with an area of about $74 \%$, which is very prone to flooding (Figure $2 b$ ).

\section{Distance from the river}

When the river overflows, the area closest to the river is the area most affected by flooding (Fernández \& Lutz, 2010). The river is the lowest point of an area. When the distance from the river is further away, the slope and elevation will also increase, and as a result, areas far from the river will have a low vulnerability to flooding events (Das, 2018). The distance from the river in several previous studies is the most significant variable in flood mapping, so it has the highest score weight compared to other variables (Rahmati et al., 2016; Bathrellos et al., 2017; Ahmed M. Youssef \& Hegab, 2019; Ajjur \& Mogheir, 2020; Olii et al., 2021; Handini et al., 2021). The results of the Euclidean Distance with an interval of 300 meters at the research site are shown in Figure 2c. The distance of 300 meters from a river in the study is most prone to flooding, and the area is about $24 \%$ of the total area.

\section{Soil type}

The type of soil in this study is to see the characteristics of saturation or soil saturation. Soil types at the research site were udipsamments, fluvaquentic endoaquepts, endoaquepts, and epiaquepts. These four soil types have different saturation levels, impacting 
water drainage through the soil horizon layer. Based on the description from USDA (1999) Soil type:

a. Udipsamments have soil characteristics that are not saturated with water in a layer up to a distance of $100 \mathrm{~cm}$ from the soil surface, even for 20-30 days in a row, because the size of the soil fraction is $0.02-2 \mathrm{~mm}$. Udipsamments formed from the sand result from marine deposition processes, so this type of soil has good drainage.

b. Fluvaquentic endoaquepts, the difference with other endoaquepts is that there is organic content at a depth of $125 \mathrm{~cm}$. With aquic conditions only in the regular year, this type of soil has moderate drainage.

c. Epiaquepts is a type of soil that has episaturation, in the sense that there are one or more layers that are saturated with water to a depth of $200 \mathrm{~cm}$. The groundwater also fluctuates to that depth so that this soil type has moderate drainage.

d. Endoaquepts are aquepts that have endosaturation, or saturated soil in all layers. Groundwater fluctuations from near the surface to a depth of $50 \mathrm{~cm}$ does not have a soil horizon to a depth of $100 \mathrm{~cm}$, as a result of the shallow groundwater table, so that when saturated with the Flat surface land will cause flooding more quickly, so this type of soil has poor drainage.

Therefore, the drainage conditions at the research site were divided into three categories: good drainage for udipsamment soil types, moderate drainage for fluvaquentic endoaquepts and epiaquepts soil types, and poor drainage for endoaquepts soil types. The highest weighting for flood susceptibility was endoaquepts which covered almost the entire study area, about $93.8 \%$ (Figure 2d).

\section{Topographic Wetness Index (TWI)}

TWI can describe the spatial distribution and areas with relatively wet and relatively dry proportions (Zhu, 2016). TWI also indicates the influence of flow direction and flow accumulation at a location in the watershed (Das, 2018). Based on the value criteria, the area with a high TWI value will be very prone to flooding. The TWI value is very prone to flooding, according to Das $(2018,2020)$, with a TWI value of $>16$, and Ahmed M. Youssef \& Hegab (2019)with a TWI value of $>14$. The variation of the TWI value in this study is between 5 and 18. The TWI values that are very prone to flooding in this study are $>14$, spread out only about $2 \%$ of the research area. The low TWI value $(<9)$ has the widest distribution, which is about $64 \%$ of the entire study area (Figure 2e). 
Muhammad Asyroful Mujib et al. / Geosfera Indonesia 6 (3), 2021, 353-376

$\mathbf{a}$

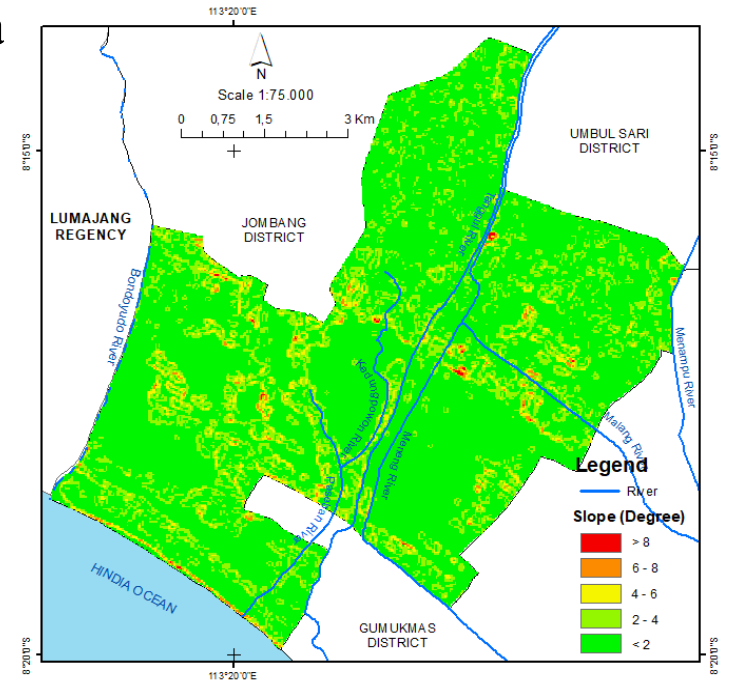

c

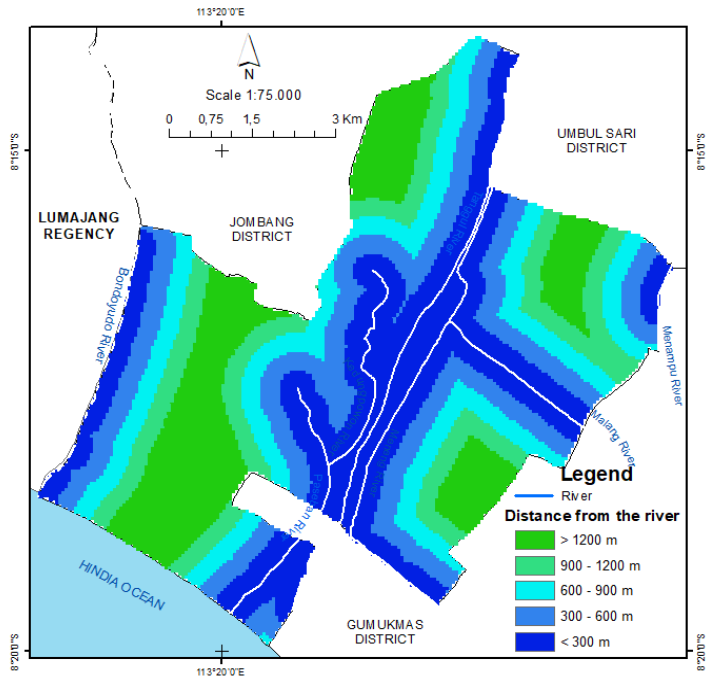

e

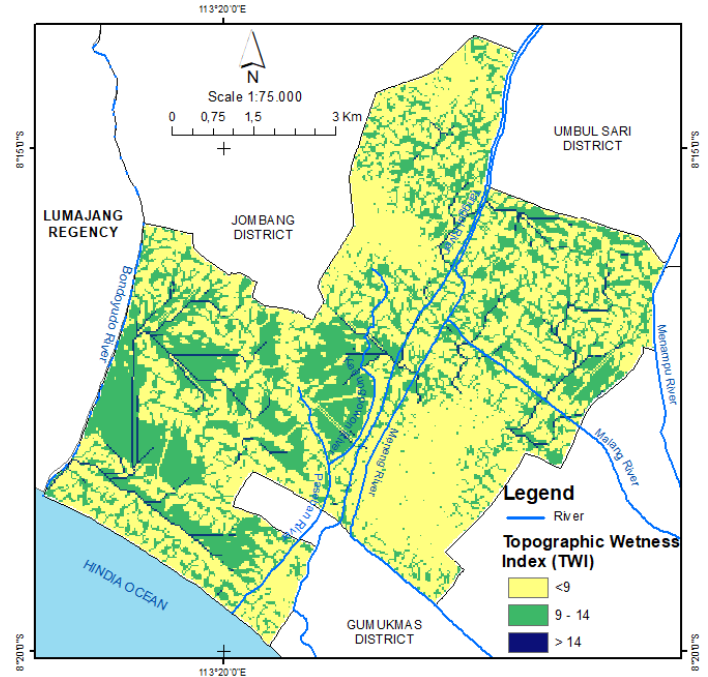

b

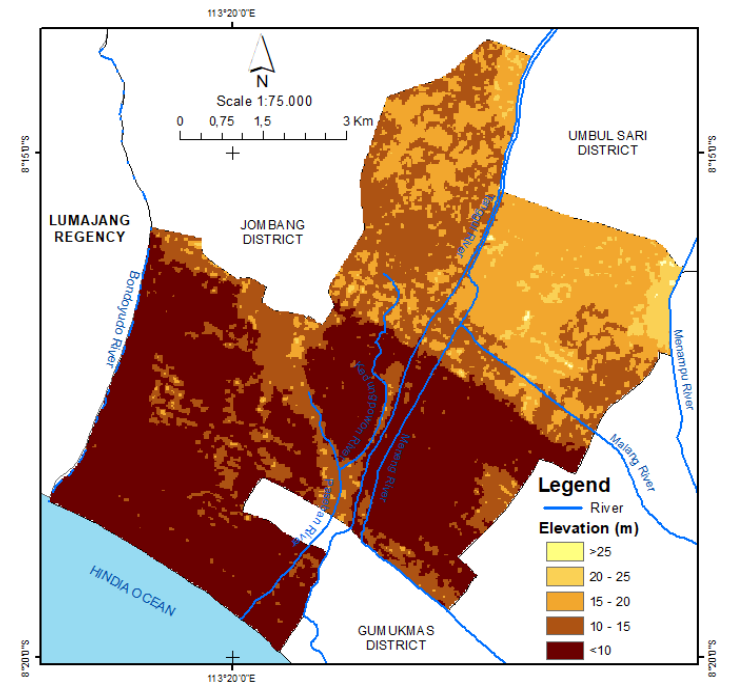

d

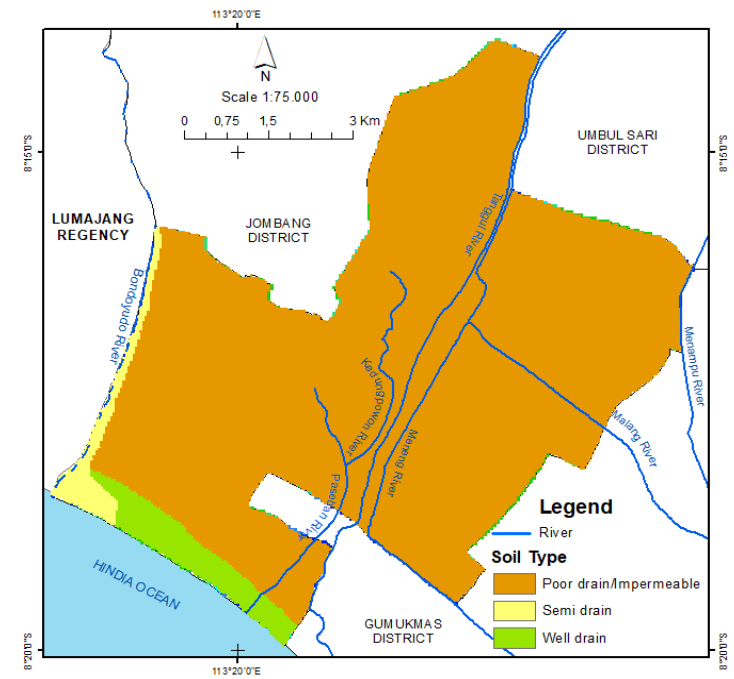

$\mathbf{f}$

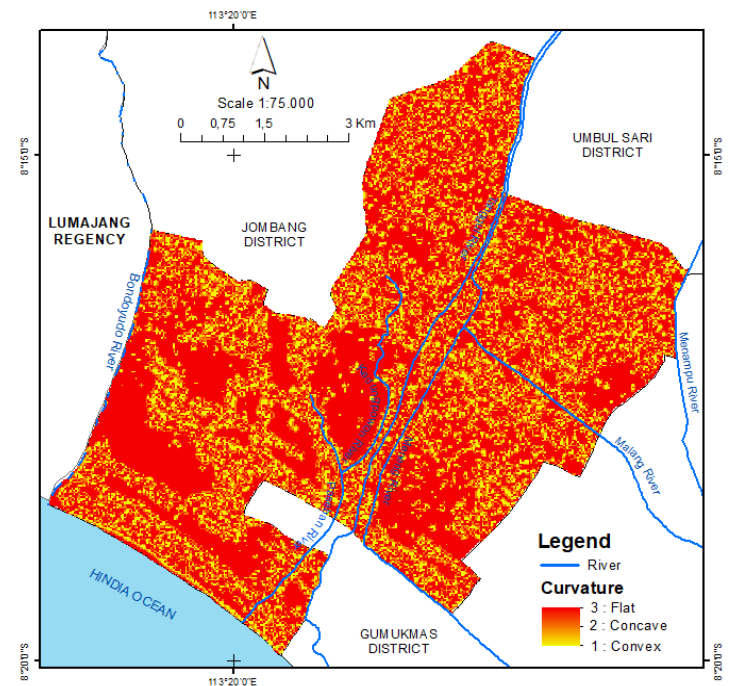

Figure 2. Factors for flood hazard mapping: a. Slope; b. Elevation; c. Distance from the river; d. Soil Type; e. Topographic Wetness Index (TWI); f. Curvature 


\section{Curvature}

Curvature has a minor influence on flood events, although it cannot be ruled out (Das, 2018). A positive curvature value indicates a convex surface (such as hills and ridges), a negative curvature value indicates a concave surface (such as depression and valley), and a value close to zero indicates flatness (Das, 2018; Zhu, 2016). The flat curvature is an area that is very prone to flooding, having the most expansive area, which is around $64.6 \%$ of the entire research area. The concave area is around $17.4 \%$, and the convex area is around $17.6 \%$ of the research area (Figure 2f).

\subsection{Comparison and Weighting of Each Factor}

This study used the AHP Excel template and the AHP Extension in ArcGIS Software to compare and calculate the weights of each variable and the Consistency Ratio (CR). The results of the first stage of AHP calculations assess all factors' weights and comparisons using a 6 × 6 matrix, with diagonal elements equal to 1 (Table 1). Furthermore, the pairwise comparison value is normalized to obtain a weighted value (Table 2). The factors in the row matrix are compared to other factors in the column matrix.

Floods in Kencong District occurred because many were caused by overflowing river water and broken river embankments so that most areas close to rivers were often affected by floods. Therefore, the distance from the river is the most influential factor compared to other factors. The distance from the river weighs 0.33 or $33 \%$, with the most flood-prone class being the area within 300 meters of the river. The distance factor from the river as the most influential factor compared to other factors is also similar to previous studies, namely Olii et al. (2021) with a weight of 0.35; Ajjur \& Mogheir (2020) with a weight of 0.38; Ahmed M. Youssef \& Hegab (2019) with a weight of 0.335; Bathrellos et al. (2017) with a weight of 0.30; and Rahmati et al. (2016) with a weight of 0.546. They all concluded that the areas most affected by flooding were areas close to rivers.

Table 1. Comparison matrix and the relative score of all flood-related factors

\begin{tabular}{lcccccc}
\hline \multicolumn{1}{c}{ Factors } & Slope & Elevation & $\begin{array}{c}\text { Distance from } \\
\text { River }\end{array}$ & Soil type & TWI & Curvature \\
\hline Slope & 1 & 4 & $1 / 2$ & 3 & 2 & 3 \\
Elevation & $1 / 4$ & 1 & $1 / 4$ & $1 / 2$ & $1 / 3$ & $1 / 2$ \\
Distance from River & 2 & 4 & 1 & 4 & 3 & 2 \\
Soil type & $1 / 3$ & 2 & $1 / 4$ & 1 & $1 / 3$ & $1 / 2$ \\
TWI & $1 / 2$ & 3 & $1 / 3$ & 3 & 1 & 3 \\
Curvature & $1 / 3$ & 2 & $1 / 2$ & 2 & $1 / 3$ & 1 \\
\hline
\end{tabular}


Muhammad Asyroful Mujib et al. / Geosfera Indonesia 6 (3), 2021, 353-376

Table 2. Normalized and the weight values in the comparison matrix

\begin{tabular}{lcccccccc}
\hline \multicolumn{1}{c}{ Factors } & Slope & Elevation & $\begin{array}{c}\text { Distance } \\
\text { from River }\end{array}$ & $\begin{array}{c}\text { Soil } \\
\text { type }\end{array}$ & TWI & Curvature & $\begin{array}{c}\text { Weights } \\
\left(\mathrm{W}_{\mathrm{i}}\right)\end{array}$ & $\begin{array}{c}\text { Weights } \\
(\%)\end{array}$ \\
\hline Slope & 0.226 & 0.250 & 0.176 & 0.222 & 0.286 & 0.300 & 0.243 & 24.3 \\
Elevation & 0.057 & 0.063 & 0.088 & 0.037 & 0.048 & 0.050 & 0.057 & 5.7 \\
Distance from River & 0.453 & 0.250 & 0.353 & 0.296 & 0.429 & 0.200 & 0.330 & 33.0 \\
Soil type & 0.075 & 0.125 & 0.088 & 0.074 & 0.048 & 0.050 & 0.077 & 7.7 \\
TWI & 0.113 & 0.188 & 0.118 & 0.222 & 0.143 & 0.300 & 0.181 & 18.1 \\
Curvature & 0.075 & 0.125 & 0.176 & 0.148 & 0.048 & 0.100 & 0.112 & 11.2 \\
\hline
\end{tabular}

The second factor that influences the occurrence of flooding is the slope with a weight of 0.24 or $24 \%$, more significant than the weight of TWI, Curvature, Soil Type, and Elevation. The slope is a physical factor that forms a disaster whose influence is still below the main factor. Most of the slopes in the study area are between $2^{\circ}$ to $4^{\circ}$, which are divided into two sub-categories of slope classes. Compared to other studies, slopes $<6^{\circ}$ are still the class most prone to flooding (Olii et al.2021; Das, 2018; Bathrellos et al.2017; Rahmati et al.2016).

The result of the Consistency Ratio (CR) calculation is 0.047 . CR value is still below the value of 0.10 ; The weighting is accepted and can be analyzed further for the subcategories of each factor. The contribution of each class in determining the flood hazard area is described in Table 3. The factors of slope, elevation and distance from the river are divided into five classes, while soil type, TWI, and Curvature are divided into three classes. Class 1 is the class that has the minor effect on flooding, and class 5 is the class that has the most influence on flood events.

Based on the results of the weighting in this study, the elevation factor is the factor that has the most negligible effect on flooding due to the elevation in the study area is almost at an altitude below $20 \mathrm{~m}$ because it is in the downstream area and covers one sub-district. In contrast, in other studies covering areas ranging from upstream to downstream and regional scale (watershed), the elevation factor is considered to be very influential. Other studies categorize elevations $<20 \mathrm{~m}$ as being in the most flood-prone area because of the regional scale of the research area (Hammami et al., 2019; Ajjur \& Mogheir, 2020; Olii et al.2021). 
Muhammad Asyroful Mujib et al. / Geosfera Indonesia 6 (3), 2021, 353-376

Table 3. Classes of the factors and according weights

\begin{tabular}{|c|c|c|c|c|c|c|c|c|c|c|c|}
\hline \multirow{2}{*}{ Factors } & \multirow{2}{*}{ Class } & \multirow{2}{*}{ Rate } & \multicolumn{5}{|c|}{ Comparison Matrix } & \multirow{2}{*}{$\begin{array}{c}\text { Class } \\
\text { Weight }\end{array}$} & \multirow{2}{*}{$\begin{array}{l}\text { Factor } \\
\text { Weight }\end{array}$} & \multirow{2}{*}{$\begin{array}{l}\text { Area } \\
\left(\mathbf{k m}^{2}\right)\end{array}$} & \multirow{2}{*}{$\begin{array}{c}\text { Area } \\
(\%)\end{array}$} \\
\hline & & & 1 & 2 & 3 & 4 & 5 & & & & \\
\hline \multirow{5}{*}{ Slope $\left(^{\circ}\right)$} & $<2^{\circ}$ & 5 & 1 & & & & & 0.416 & 0.243 & 46.87 & 78.65 \\
\hline & $2-4^{\circ}$ & 4 & $1 / 2$ & 1 & & & & 0.262 & & 10.46 & 17.56 \\
\hline & $4-6^{\circ}$ & 3 & $1 / 3$ & $1 / 2$ & 1 & & & 0.161 & & 1.83 & 3.07 \\
\hline & $6-8^{\circ}$ & 2 & $1 / 4$ & $1 / 3$ & $1 / 2$ & 1 & & 0.099 & & 0.36 & 0.62 \\
\hline & $>8^{\circ}$ & 1 & $1 / 5$ & $1 / 4$ & $1 / 3$ & $1 / 2$ & 1 & 0.062 & & 0.05 & 0.09 \\
\hline \multirow{5}{*}{$\begin{array}{l}\text { Elevation } \\
\quad(\mathbf{m})\end{array}$} & $<10$ & 5 & 1 & & & & & 0.416 & 0.057 & 28.11 & 47.15 \\
\hline & $10-15$ & 4 & $1 / 2$ & 1 & & & & 0.262 & & 16.45 & 27.59 \\
\hline & $15-20$ & 3 & $1 / 3$ & $1 / 2$ & 1 & & & 0.161 & & 13.59 & 22.81 \\
\hline & $20-25$ & 2 & $1 / 4$ & $1 / 3$ & $1 / 2$ & 1 & & 0.099 & & 1.41 & 2.36 \\
\hline & $>25$ & 1 & $1 / 5$ & $1 / 4$ & $1 / 3$ & $1 / 2$ & 1 & 0.062 & & 0.03 & 0.06 \\
\hline \multirow{2}{*}{$\begin{array}{l}\text { Distance } \\
\text { from river }\end{array}$} & $<300 \mathrm{~m}$ & 5 & 1 & & & & & 0.443 & 0.330 & 28.40 & 16.91 \\
\hline & $\begin{array}{c}300-600 \\
\mathrm{~m}\end{array}$ & 4 & $1 / 3$ & 1 & & & & 0.240 & & 20.69 & 12.32 \\
\hline \multirow[t]{3}{*}{ (m) } & $\begin{array}{c}600-900 \\
\mathrm{~m}\end{array}$ & 3 & $1 / 3$ & $1 / 2$ & 1 & & & 0.159 & & 17.16 & 10.22 \\
\hline & $\begin{array}{c}900-1200 \\
\mathrm{~m}\end{array}$ & 2 & $1 / 4$ & $1 / 3$ & $1 / 2$ & 1 & & 0.097 & & 13.98 & 8.33 \\
\hline & $>1200 \mathrm{~m}$ & 1 & $1 / 5$ & $1 / 4$ & $1 / 3$ & $1 / 2$ & 1 & 0.061 & & 19.74 & 11.75 \\
\hline \multirow[t]{3}{*}{ Soil Type } & Poor drain & 3 & 1 & & & & & 0.633 & 0.077 & 56.01 & 93.85 \\
\hline & $\begin{array}{l}\text { Semi } \\
\text { drain }\end{array}$ & 2 & $1 / 3$ & 1 & & & & 0.260 & & 1.42 & 2.37 \\
\hline & Well drain & 1 & $1 / 5$ & $1 / 3$ & 1 & & & 0.106 & & 2.26 & 3.78 \\
\hline \multirow[t]{3}{*}{ TWI } & $>14$ & 3 & 1 & & & & & 0.633 & 0.181 & $1 ., 21$ & 2.07 \\
\hline & $9-14$ & 2 & $1 / 3$ & 1 & & & & 0.260 & & 19.43 & 33.30 \\
\hline & $<9$ & 1 & $1 / 5$ & $1 / 3$ & 1 & & & 0.106 & & 37.70 & 64.63 \\
\hline \multirow[t]{3}{*}{ Curvature } & Flat & 3 & 1 & & & & & 0.599 & 0.112 & 38.56 & 64.69 \\
\hline & Concave & 2 & $1 / 3$ & 1 & & & & 0.269 & & 10.43 & 17.49 \\
\hline & Convex & 1 & $1 / 4$ & $1 / 3$ & 1 & & & 0.131 & & 10.62 & 17.81 \\
\hline
\end{tabular}

4.3. Flood Susceptibility Analysis Results

The value of the weight of each class and weight variables from the AHP model is then included in the Weighted Overlay analysis in ArcGIS according to the classes described in Table 3. The flood hazard map resulting from the weighting of the six variables is shown in Figure 3. Flood hazard is divided into five levels: deficient, low, medium, high, and very high with an area of $0.02 \%$ each; $4.26 \% ; 37.11 \% ; 51.89 \%$, and $6.72 \%$. The location of the occurrence of flooding observations based on incident records and interviews was found as many as 121 locations, of which there were 14 observation sites in moderately vulnerable areas, 81 observation locations in high-prone areas, and 26 observation locations in very high flood-prone areas (Table 4). Most flood locations are found in high flood-prone areas because they cover an area of $30.19 \mathrm{~km}^{2}$ or equivalent to $50.89 \%$ of the total research area. In areas with a very high level of flood susceptibility, 26 locations were also found, although the area 
was only $3.91 \mathrm{~km}^{2}$ or $6.72 \%$. In contrast, in areas with a deficient and low level of flood susceptibility with an area of $4.28 \%$, there were no locations where there had been a flood.

Table 4. Areas according to the level of flood susceptibility and flood observation locations

\begin{tabular}{lccc}
\hline \multicolumn{1}{c}{ Flood Hazard Classes } & Area $\left.\mathbf{( k m}^{\mathbf{2}}\right)$ & Area $(\%)$ & Inventory Flood Mapping \\
\hline Very Low & 0.013 & 0.02 & - \\
Low & 2.477 & 4.26 & - \\
Medium & 21.598 & 37.11 & 14 \\
High & 30.196 & 51.89 & 81 \\
Very High & 3.911 & 6.72 & 26 \\
Total & 58.195 & 100.00 & 121 \\
\hline
\end{tabular}

Areas with a very high level of flood vulnerability are in the middle part of Kraton Village (2.45\%) and the southern part of Kencong Village (2.37\%). These two villages have experienced seven broken embankments since 1994. The river embankment that broke on December 22, 2018, was the left-hand defence of the Tanggul River which then resulted in flooding in the southern part of Kencong Village and Kraton Village. Very high vulnerability areas are close to rivers, flat slopes $<2^{\circ}$, low elevation, poor soil drainage, and the density of drainage between the Kedongpawon River, Tanggul River, and Meneng River at this location is very tight. The density of dense river drainage is one factor that encourages flood inundation (Danumah et al., 2016; Dahri \& Abida, 2017; Seejata et al., 2018). In addition, regarding the broken embankment, a very high flood-prone area is also located at the confluence of the Paseban River and the Kedungpowon River. Chakraborty \& Mukhopadhyay (2019) stated that the proximity of an area to the confluence of two rivers and a broken embankment significantly influences flood vulnerability. According to the flood susceptibility class, the area of the village is described in Table 5.

Table 5. The area of the village, according to the level of flood susceptibility

\begin{tabular}{|c|c|c|c|c|c|c|c|c|c|c|c|}
\hline \multirow{3}{*}{ Village } & \multicolumn{10}{|c|}{ Hazard Classes } & \multirow{3}{*}{$\begin{array}{c}\text { Total } \\
\left(\mathrm{km}^{2}\right)\end{array}$} \\
\hline & \multicolumn{2}{|c|}{ Very Low } & \multicolumn{2}{|c|}{ Low } & \multicolumn{2}{|c|}{ Medium } & \multicolumn{2}{|c|}{ High } & \multicolumn{2}{|c|}{ Very High } & \\
\hline & $\mathrm{Km}^{2}$ & $\%$ & $\mathbf{K m}^{2}$ & $\%$ & $\mathbf{K m}^{2}$ & $\%$ & $\mathrm{Km}^{2}$ & $\%$ & $\mathrm{Km}^{2}$ & $\%$ & \\
\hline Cakru & & & 0.51 & 0.87 & 3.57 & 6.14 & 3.67 & 6.31 & 0.38 & 0.66 & 22.11 \\
\hline Kencong & & & 0.48 & 0.83 & 5.70 & 9.80 & 9.91 & 17.02 & 1.38 & 2.37 & 45.11 \\
\hline Kraton & & & 0.04 & 0.07 & 1.03 & 1.77 & 5.55 & 9.54 & 1.42 & 2.45 & 19.44 \\
\hline Paseban & 0.013 & 0.02 & 0.86 & 1.48 & 5.05 & 8.68 & 4.98 & 8.56 & 0.31 & 0.53 & 29.96 \\
\hline Wonorejo & & & 0.58 & 1.00 & 6.24 & 10.72 & 6.08 & 10.45 & 0.42 & 0.72 & 35.50 \\
\hline Total & 0.013 & & 2.48 & & 21.60 & & 30.20 & & 3.91 & & 58.20 \\
\hline
\end{tabular}

Areas with high flood susceptibility have $51.89 \%$ of the research area. High flood levels were spread across all villages, such as in Kencong Village (17.02\%), Wonorejo Village (10.45\%), and Kraton Village (9.54\%). The dominant high flood-prone class is within 300-500 meters of the river, namely the Tanggul River, Malang River, Meneng River, 
Kedungpowon River, and Bondoyudo River. The flood caused by the embankment breaks, all areas categorized as high flood-prone will also be inundated. The slopes in Kencong District are dominantly in the flat category with slopes of $0^{\circ}-4^{\circ}$, low elevation, and poor drainage, which makes some areas fall into the category of high-level flooding.

Areas that have a moderate level of flood vulnerability are Wonorejo Village (10.72\%), Kencong Village (9.80\%), and Paseban Village (8.68\%). The condition of the area included in the moderate flood area is usually caused by the movement of water through the basin and basin to lead to a flat place even though it is far from the river. They are randomly distributed in the low- and very-low class flood areas. The area is far from rivers, has good soil drainage, and has curvature in hills or dunes. The distribution of all flood-prone classes is shown in Figure 3.

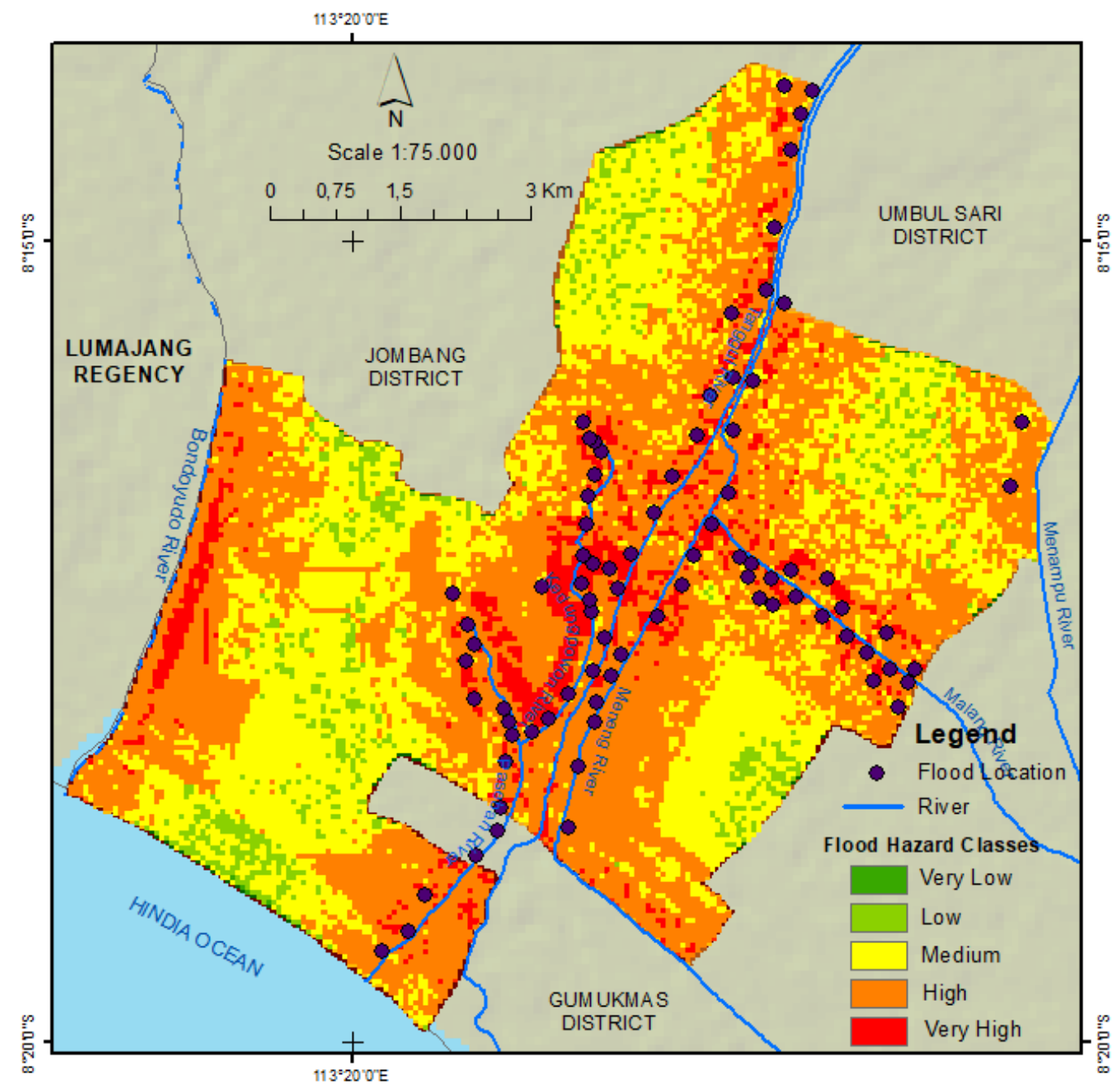

Figure 3. Flood susceptibility map 


\subsection{Model Validation}

The accuracy of the flood vulnerability modeling results can be validated quantitatively using the Receiver Operating Characteristic (ROC) curve to compare the accuracy of the vulnerability map with data on the location of flood events in the field (Youssef \& Hegab, 2019; Shafizadeh-Moghadam et al., 2018; Tien Bui et al., 2012). In general, the prediction level shows the model's predictive ability in a particular area by measuring the area under the prediction level curve (Area Under Curve) called the AUC Value (Pourghasemi et al., 2012).

In this study, the validation of the flood-prone map was carried out through field observations at locations that had been flooded and found 121 locations of flood events in the Kencong District area. The AUC value shows a value of 0.838 which means that about $84 \%$ of the area is below the prediction according to the AHP flood mapping method results (Figure 4). The range of values to indicate the predicted result class is 90-100\% (Special); 8090\% (Very Good); 70-80\% (Good); 60-70\% (Enough); and 50-60\% (low) (James et al., 2013; Zumel \& Mount, 2014). The AUC value shows that the AHP method has excellent predictive ability (84\%) in mapping flood-prone areas in Kencong District.

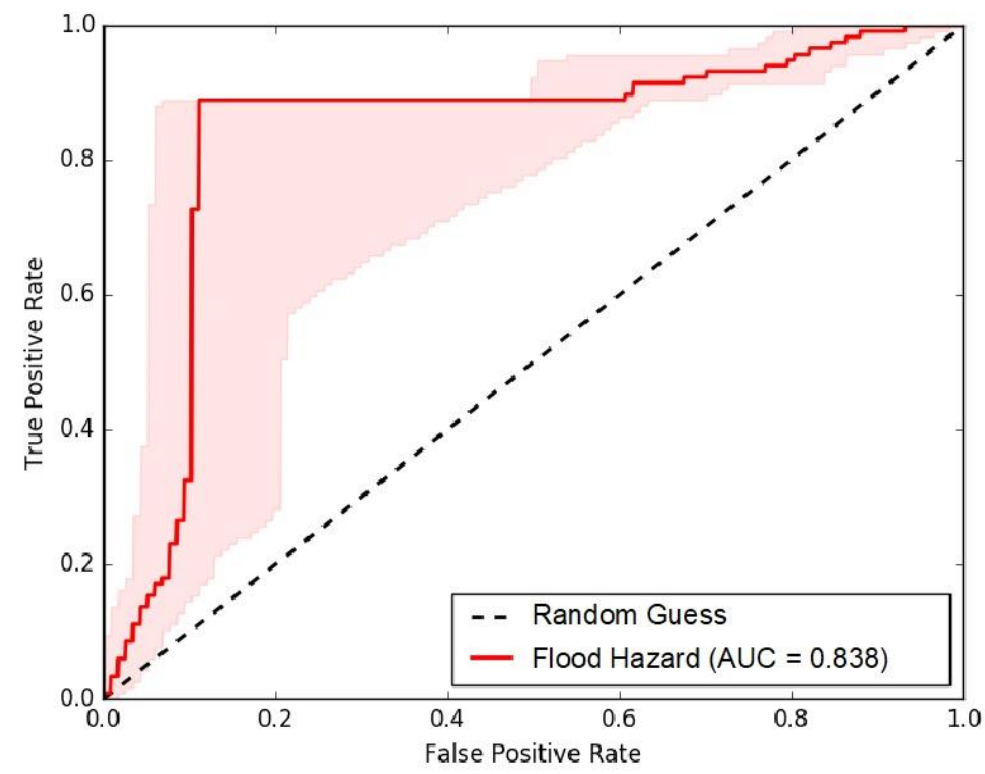

Figure 4. Area Under Curve (AUC) for Flood Susceptibility Map

\section{Conclusion}

The AHP method, integrated with the Geographic Information System, can produce a model to evaluate the spatial distribution of flood-prone areas in the Kencong District, Jember Regency. Spatial distribution using weighting on the variables of a slope, elevation, 
soil type, distance from the river, topographic wetness index (TWI), and curvature have been divided into five levels: deficient, low, medium, high, and very high with an area of $0.02 \%$ each; $4.26 \% ; 37.11 \% ; 51.89 \%$, and $6.72 \%$. Areas closed to the rivers within a radius of $<300$ meters, and 300-600 meters are high vulnerable to the flood, because the distance variable has the highest weight, which is about $33 \%$ compared to other variables. The farther the distance from the river, the lower the potential for the area flooded. The validation value of this model with observations in the field was $83.8 \%$, indicating a excellent predictive ability.

\section{Conflict of Interest}

The authors declare that there is no conflict of interest with any financial, personal, or other relationships with other people or organizations related to the material discussed in this article.

\section{References}

Ainunisa, D., Halik, G., \& Widiarti, W. Y. (2020). Pemodelan Perubahan Tataguna Lahan Terhadap Debit Banjir DAS Tanggul, Jember Menggunakan Model SWAT (Soil and Water Assessment Tool). Rekayasa Sipil, 14(2), 154-161. https://doi.org/10.21776/ub.rekayasasipil.2020.014.02.10.

Ajjur, S. B., \&Mogheir, Y. K. (2020). Flood hazard mapping using a multi-criteria decision analysis and GIS (case study Gaza Governorate, Palestine). Arabian Journal of Geosciences, 13(2). https://doi.org/10.1007/s12517-019-5024-6.

Arseni, M., Rosu, A., Calmuc, M., Calmuc, V. A., Iticescu, C., \& Georgescu, L. P. (2020). Development of flood risk and hazard maps for the lower course of the Siret River, Romania. Sustainability (Switzerland), 12(16). https://doi.org/10.3390/su12166588.

Bachri, S., Aldianto, Y. E., Sumarmi;, Kresno, S. B. U. ., \& Naufal, M. F. (2021). Flood Modelling of Badeng River Using HEC-RAS in Singojuruh Sub-District, Banyuwangi Regency, East Java, Indonesia. Jurnal Geografi, 13(1), 76-87. https://doi.org/10.24114/jg.v13i1.19211.

Balica, S. F., Popescu, I., Beevers, L., \& Wright, N. G. (2013). Parametric and physically based modelling techniques for flood risk and vulnerability assessment: A comparison. Environmental Modelling and Software, 41, 84-92. https://doi.org/10.1016/j.envsoft.2012.11.002.

Bathrellos, G. D., Skilodimou, H. D., Chousianitis, K., Youssef, A. M., \& Pradhan, B. (2017). Suitability estimation for urban development using multi-hazard assessment map. Science of the Total Environment, 575, 119-134. https://doi.org/10.1016/j.scitotenv.2016.10.025.

Bellos, V. (2012). Ways for flood hazard mapping in urbanised environments: A short literature review. Water Utility Journal, January 2012, 25-31. https://www.ewra.net/wuj/pdf/WUJ_2012_04_03.pdf. 
BNPB. (2019). Katalog Desa/Kelurahan Rawan Banjir (Kelas Kerawanan Tinggi dan Sedang). Retrieved from https://bnpb.go.id/.

BNPB. (2021). Indeks risiko bencana Indonesia (IRBI) tahun 2020. Retrieved from https://bnpb.go.id/.

Carmo, J. S. A. (2020). Physical Modelling vs. Numerical Modelling: Complementarity and Learning. Preprints (Www.Preprints.Org), July. https://doi.org/10.20944/preprints202007.0753.v1.

Chakraborty, S., \& Mukhopadhyay, S. (2019). Assessing flood risk using analytical hierarchy process (AHP) and geographical information system (GIS): application in Coochbehar district of West Bengal, India. Natural Hazards, 99(1), 247-274. https://doi.org/10.1007/s11069-019-03737-7.

Costache, R. (2019). Flood Susceptibility Assessment by Using Bivariate Statistics and Machine Learning Models - A Useful Tool for Flood Risk Management. Water Resources Management, 33(9), 3239-3256. https://doi.org/10.1007/s11269-01902301-z.

Costache, R., Arabameri, A., Elkhrachy, I., Ghorbanzadeh, O., \& Pham, Q. B. (2021). Detection of areas prone to flood risk using state-of-the-art machine learning models. Geomatics, Natural Hazards and Risk, 12(1), 1488-1507. https://doi.org/10.1080/19475705.2021.1920480.

Dahri, N., \& Abida, H. (2017). Monte Carlo simulation-aided analytical hierarchy process (AHP) for flood susceptibility mapping in Gabes Basin (southeastern Tunisia). Environmental Earth Sciences, 76(7). https://doi.org/10.1007/s12665-017-6619-4.

Danumah, J. H., Odai, S. N., Saley, B. M., Szarzynski, J., Thiel, M., Kwaku, A., Kouame, F. K., \& Akpa, L. Y. (2016). Flood risk assessment and mapping in Abidjan district using multi-criteria analysis (AHP) model and geoinformation techniques, (cote d'ivoire). Geoenvironmental Disasters, 3(1). https://doi.org/10.1186/s40677-0160044-y.

Das, S. (2018). Geographic information system and AHP-based flood hazard zonation of Vaitarna basin, Maharashtra, India. Arabian Journal of Geosciences, 11(19). https://doi.org/10.1007/s12517-018-3933-4.

Das, S. (2019). Geospatial mapping of flood susceptibility and hydro-geomorphic response to the floods in Ulhas basin, India. Remote Sensing Applications: Society and Environment, 14, 60-74. https://doi.org/10.1016/j.rsase.2019.02.006.

Das, S. (2020). Flood susceptibility mapping of the Western Ghat coastal belt using multisource geospatial data and analytical hierarchy process (AHP). Remote Sensing Applications: $\quad$ Society and Environment, 20, 100379. https://doi.org/10.1016/j.rsase.2020.100379.

Das, S., \& Pardeshi, S. D. (2018). Comparative analysis of lineaments extracted from Cartosat, SRTM and ASTER DEM: a study based on four watersheds in Konkan region, India. Spatial Information Research, 26(1), 47-57. https://doi.org/10.1007/s41324-017-0155-x. 
Djalante, R., \& Garschagen, M. (2017). A Review of Disaster Trend and Disaster Risk Governance in Indonesia:1900-2015. In Disaster Risk Reduction in Indonesia.https://doi.org/10.1007/978-3-319-54466-3_2.

Eini, M., Kaboli, H. S., Rashidian, M., \& Hedayat, H. (2020). Hazard and vulnerability in urban flood risk mapping: Machine learning techniques and considering the role of urban districts. International Journal of Disaster Risk Reduction, 50, 101687. https://doi.org/10.1016/j.ijdrr.2020.101687.

Feng, L. H., \& Lu, J. (2010). The practical research on flood forecasting based on artificial neural networks. Expert Systems with Applications, 37(4), 2974-2977. https://doi.org/10.1016/j.eswa.2009.09.037.

Fernández, D. S., \& Lutz, M. A. (2010). Urban flood hazard zoning in Tucumán Province, Argentina, using GIS and multicriteria decision analysis. Engineering Geology, 111(1-4), 90-98. https://doi.org/10.1016/j.enggeo.2009.12.006.

Hammami, S., Zouhri, L., Souissi, D., Souei, A., Zghibi, A., Marzougui, A., \& Dlala, M. (2019). Application of the GIS based multi-criteria decision analysis and analytical hierarchy process (AHP) in the flood susceptibility mapping (Tunisia). Arabian Journal of Geosciences, 12(21). https://doi.org/10.1007/s12517-019-4754-9.

Handini, D. R., Hidayah, E., \& Halik, G. (2021). Flash Flood Susceptibility Mapping at Andungbiru Watershed, East Java Using AHP-Information Weighted Method. Geosfera Indonesia, 6(2), 157-172. https://doi.org/https://doi.org/10.19184/geosi.v6i2.24173.

Haq, T., Halik, G., \& Hidayah, E. (2020). Flood routing model using integration of Delft3D and GIS (case study: Tanggul watershed, Jember). AIP Conference Proceedings, 2278(October). https://doi.org/10.1063/5.0014607.

Ho, L. T. K., \& Umitsu, M. (2011). Micro-landform classification and flood hazard assessment of the Thu Bon alluvial plain, central Vietnam via an integrated method utilizing remotely sensed data. Applied Geography, 31(3), 1082-1093. https://doi.org/10.1016/j.apgeog.2011.01.005.

James, G., Witten, D., Hastie, T., \& Tibshirani, R. (2013). An Introduction to Statistical Learning, With application in R. Springer: US.

Ji, J., Choi, C., Yu, M., \& Yi, J. (2012). Comparison of a data-driven model and a physical model for flood forecasting. WIT Transactions on Ecology and the Environment, 159, 133-142. https://doi.org/10.2495/FRIAR120111.

Kazakis, N., Kougias, I., \& Patsialis, T. (2015). Assessment of flood hazard areas at a regional scale using an index-based approach and Analytical Hierarchy Process: Application in Rhodope-Evros region, Greece. Science of the Total Environment, 538, 555-563. https://doi.org/10.1016/j.scitotenv.2015.08.055.

Kia, M. B., Pirasteh, S., Pradhan, B., Mahmud, A. R., Sulaiman, W. N. A., \& Moradi, A. (2012). An artificial neural network model for flood simulation using GIS: Johor River Basin, Malaysia. Environmental Earth Sciences, 67(1), 251-264. https://doi.org/10.1007/s12665-011-1504-z. 
Mahmoud, S. H., \& Gan, T. Y. (2018). Multi-criteria approach to develop flood susceptibility maps in arid regions of Middle East. Journal of Cleaner Production, 196, 216-229. https://doi.org/10.1016/j.jclepro.2018.06.047.

Mudashiru, R. B., Sabtu, N., Abustan, I., \& Balogun, W. (2021). Flood hazard mapping methods: A review. Journal of Hydrology, 603(PA), 126846. https://doi.org/10.1016/j.jhydrol.2021.126846.

Olii, M. R., Olii, A., \& Pakaya, R. (2021). The integrated spatial assessment of the flood hazard using AHP-GIS: The case study of gorontalo regency. Indonesian Journal of Geography, 53(1), 126-135. https://doi.org/10.22146/IJG.59999.

Papaioannou, G., Vasiliades, L., \& Loukas, A. (2015). Multi-Criteria Analysis Framework for Potential Flood Prone Areas Mapping. Water Resources Management, 29(2), 399418. https://doi.org/10.22146/IJG.59999.

Pelling, M. (2003). The vulnerability of cities : natural disasters and social resilience. In Earthscan Publications Ltd. https://doi.org/10.1039/J19660001254.

Pourghasemi, H. R., Pradhan, B., \& Gokceoglu, C. (2012). Application of fuzzy logic and analytical hierarchy process (AHP) to landslide susceptibility mapping at Haraz watershed, Iran. Natural Hazards, 63(2), 965-996. https://doi.org/10.1007/s11069012-0217-2.

Pourghasemi, H. reza, Beheshtirad, M., \& Pradhan, B. (2014). A comparative assessment of prediction capabilities of modified analytical hierarchy process (M-AHP) and Mamdani fuzzy logic models using Netcad-GIS for forest fire susceptibility mapping. Geomatics, Natural Hazards and Risk, 7(2), 861-885. https://doi.org/10.1080/19475705.2014.984247.

Public Works Department of Highways and Natural Resources of Jember Regency Natural Resources Coordinator Area of Kencong and Gumukmas Districts. (2018). Data on the Social Impact of the Flood in Kencong District in 2018. (Unpublished).

Public Works Department of Highways and Natural Resources of Jember Regency Natural Resources Coordinator Area of Kencong and Gumukmas Districts. (2021). Chronology and Characteristics of Flooding Along the Embankment River. (Unpublished).

Rahmati, O., Zeinivand, H., \& Besharat, M. (2016). Flood hazard zoning in Yasooj region, Iran, using GIS and multi-criteria decision analysis. Geomatics, Natural Hazards and Risk, 7(3), 1000-1017. https://doi.org/10.1080/19475705.2015.1045043.

Saaty, T. L. (1977). A scaling method for priorities in hierarchical structures. Journal of Mathematical Psychology, 15(3), 234-281. https://doi.org/10.1016/00222496(77)90033-5.

Saaty, T. L. (1990). How to make a decision: The analytic hierarchy process. European Journal of Operational Research, 48(1), 9-26. https://doi.org/10.1016/03772217(90)90057-I. 
Saaty, T. L. (2004). Decision making - the Analytic Hierarchy and Network Processes (AHP/ANP). Journal of Systems Science and Systems Engineering, 13(1), 1-35. https://doi.org/10.1007/s11518-006-0151-5.

Samanta, S., Koloa, C., Pal, D. K., \& Palsamanta, B. (2016). Flood risk analysis in lower part of Markham river based on multi-criteria decision approach (MCDA). Hydrology, 3(3), 1-13. https://doi.org/10.3390/hydrology3030029.

Satty, T. L. (1980). The Analytic Hierarchy Process: Planning, Priority Setting, Resource Allocation. In McGrow, New York. https://doi.org/10.1201/9780429504419-2.

Seejata, K., Yodying, A., Wongthadam, T., Mahavik, N., \& Tantanee, S. (2018). Assessment of flood hazard areas using Analytical Hierarchy Process over the Lower Yom Basin, Sukhothai Province. Procedia Engineering, 212, 340-347. https://doi.org/10.1016/j.proeng.2018.01.044.

Shafizadeh-Moghadam, H., Valavi, R., Shahabi, H., Chapi, K., \& Shirzadi, A. (2018). Novel forecasting approaches using combination of machine learning and statistical models for flood susceptibility mapping. Journal of Environmental Management, 217, 1-11. https://doi.org/10.1016/j.jenvman.2018.03.089.

Siregar, R. I., \& Indrawan, I. (2017). Studi Komparasi Pemodelan 1-D (Satu Dimensi) Dan 2D (Dua Dimensi) Dalam Memodelkan Banjir Das Citarum Hulu. Educational Building, 3(2). https://doi.org/10.24114/eb.v3i2.8255.

Suwarti, T., \& Suharsono. Pusat Penelitian dan Pengembangan Geologi. (1993.). Peta geologi lembar Lumajang, Jawa = Geological map of the Lumajang quadrangle, Jawa [peta] / oleh T. Suwarti dan Suharsono. Bandung: Pusat Penelitian dan Pengembangan Geologi.

Soulsby, C., Tetzlaff, D., \& Hrachowitz, M. (2010). Spatial distribution of transit times in montane catchments: Conceptualization tools for management. Hydrological Processes, 24(22), 3283-3288. https://doi.org/10.1002/hyp.7864.

Tehrany, M. S., Pradhan, B., \& Jebur, M. N. (2013). Spatial prediction of flood susceptible areas using rule based decision tree (DT) and a novel ensemble bivariate and multivariate statistical models in GIS. Journal of Hydrology, 504, 69-79. https://doi.org/10.1016/j.jhydrol.2013.09.034.

Tehrany, M. S., Pradhan, B., Mansor, S., \& Ahmad, N. (2015). Flood susceptibility assessment using GIS-based support vector machine model with different kernel types. Catena, 125, 91-101. https://doi.org/10.1016/j.catena.2014.10.017.

Teng, J., Jakeman, A. J., Vaze, J., Croke, B. F. W., Dutta, D., \& Kim, S. (2017). Flood inundation modelling: A review of methods, recent advances and uncertainty analysis. Environmental Modelling and Software, 90, 201-216. https://doi.org/10.1016/j.envsoft.2017.01.006.

Tien Bui, D., Pradhan, B., Lofman, O., \& Revhaug, I. (2012). Landslide susceptibility assessment in vietnam using support vector machines, decision tree, and nave bayes models. Mathematical Problems in Engineering, 2012. https://doi.org/10.1155/2012/974638. 
USDA. (1999). Soil Taxonomy: A Basic System of Soil Classification for Making and Interpreting Soil Surveys, 2nd Edition.https://doi.org/10.1201/9780429445552-38.

Vorogushyn, S., Lindenschmidt, K. E., Kreibich, H., Apel, H., \& Merz, B. (2012). Analysis of a detention basin impact on dike failure probabilities and flood risk for a channeldike-floodplain system along the river Elbe, Germany. Journal of Hydrology, 436437, 120-131. https://doi.org/10.1016/j.jhydrol.2012.03.006.

Wang, Y., Hong, H., Chen, W., Li, S., Pamučar, D., Gigović, L., Drobnjak, S., Bui, D. T., \& Duan, H. (2019). A hybrid GIS multi-criteria decision-making method for flood susceptibility mapping at Shangyou, China. Remote Sensing, 11(1). https://doi.org/10.3390/rs11010062.

Youssef, A. M., Pradhan, B., Gaber, A. F. D., \& Buchroithner, M. F. (2009). Geomorphological hazard analysis along the Egyptian Red Sea coast between Safaga and Quseir. Natural Hazards and Earth System Science, 9(3), 751-766. https://doi.org/10.5194/nhess-9-751-2009.

Youssef, A. M., \& Hegab, M. A. (2019). Flood-Hazard Assessment Modeling Using Multicriteria Analysis and GIS. In Spatial Modeling in GIS and $R$ for Earth and Environmental Sciences (Issue 2017). Elsevier Inc. https://doi.org/10.1016/b978-0-12815226-3.00010-7.

Youssef, A. M., Pradhan, B., \& Sefry, S. A. (2016). Flash flood susceptibility assessment in Jeddah city (Kingdom of Saudi Arabia) using bivariate and multivariate statistical models. Environmental Earth Sciences, 75(1), 1-16. https://doi.org/10.1007/s12665015-4830-8.

Zheng, Z., Qi, S., \& Xu, Y. (2013). Questionable frequent occurrence of urban flood hazards in modern cities of China. Natural Hazards, 65(1), 1009-1010. https://doi.org/10.1007/s11069-012-0397-9.

Zhu, X. (2016). GIS for Environmental Applications: a practical approach. New York : Routledge.

Zumel, N., \& Mount, J. (2014). Practical Data Science with R. New York: Simon and Schuster. https://doi.org/10.2741/4268. 